\title{
The research on "One point to promote the whole area” of exemplary role of student party members -Institute of economy management of Beihua University as an example
}

\author{
Zhi-quan An ${ }^{1}$, Peng Zhang, ${ }^{2, *}$ \\ ${ }^{1}$ School of economics and management, Beihua University \\ ${ }^{2}$ Beihua University ,Jilin, China \\ *Corresponding author
}

Keywords: One point to promote the whole area, Student party members, Exemplary role.

\begin{abstract}
Student party members are outstanding elements in the ranks of college students. They have high prestige in the college students, and have a certain theoretical level and high political quality. They are the bridge and ligament linking the party organizations with the vast number of young students. In the construction of grass-roots party organizations, how to give full play to the vanguard and exemplary role of student party members is an important topic worthy of discussion in the party construction work of students in the new period.

College students are the main force in the construction of harmonious campus, and eventually the party members of college students will become the leader of this main force. As student party members are outstanding elements in the ranks of college students, their words and deeds represent the image of the party in the minds of College students. Therefore, how to play the vanguard exemplary role of student party members will become the focus of Party branch construction work in our hospital. Playing the vanguard and exemplary role of student party members is directly related to the attraction of the party to the young students, and more importantly, whether the young students can undertake the historical task entrusted by the party and the state in the future.

School of economics and management of the student Party branch in the school, under the correct leadership of the Party committee of college, Deng Xiaoping theory, the important thought of Three Represents Scientific Outlook on Development and nineteen spirit, the spirit of the speech series general secretary $\mathrm{Xi}$ Jinping as the guidance, and conscientiously implement the relevant requirements of our school to strengthen and improve the party's organization construction, focus on the "five catch double test" and "the two one" work arrangements, strengthen the organization, ideology, navigation and other construction activities, to seek development in practice and innovation in the development and innovation in the way, all the branch members and College teachers and students to work together, the work made some achievements, especially pay attention to play a vanguard role of student party members is even more remarkable results have been achieved in the branch.
\end{abstract}

\section{Performance of vanguard and exemplary role of student party members}

Student party members have good political quality and the level of knowledge, whether in the theory of knowledge learning, work, or ideological and moral construction can lead to real through their practical actions to play a vanguard role. In this way, through the students to educate students, so as to achieve the "no teaching and teaching" the highest educational purpose.

First, drive learning. The central task of college students is to study. Learn professional knowledge is very important, Party members of our college students complete their learning tasks at 
the same time also can pay attention to the side of the students learning, especially at the end of the semester to help poor students to test counseling, pay special attention to the students love the Internet, they promptly to dissuade. Professional special needs also often organize some party and group knowledge competition, give students encouragement, in the entertainment at the same time enable students to master more knowledge. In addition, student party members use their own actions to create a good, advanced, advanced, with a good atmosphere behind, to form, learn, catch, help, ultra-learning atmosphere.

Second, leading the thought. In the ideological construction, through the branch to carry out five catch double test "and" two do "as the theme of learning. The Party branch can learn the party constitution by means of multimedia and other channels, and learn a series of important speeches by the general secretary, and strive for the qualified members of the Communist Party of China who are members of the Communist Party of china. Through the study, the members of the Party branch have clearly defined the responsibilities and obligations of the party members in the new period, so as to make them clear the direction of future efforts. They also make clear to hold high the great banner of socialism Chinese, Marx adhere to the Lenin doctrine, Mao Zedong thought, Deng Xiaoping theory and the important thought of "Three Represents" and Scientific Outlook on Development as a guide, to strengthen the branch of all members of Marx's view of mass education, to implement the provisions of the central eight as a starting point, to further highlight style building, resolutely oppose formalism, bureaucracy, hedonism and wasteful. Through the study, it also makes the branch students know that the party members should have the spirit of serving the people wholeheartedly, and they should bring their classmates around with their own efforts, and play a vanguard and exemplary role everywhere.

Third, pass civilization. Branch of student party members consciously abide by state laws, abide by the rules of the school, to avoid any misconduct. Branch Party members in the Qingming Festival, organize students to attend the tomb sweeping activities; in the spare time will organize students to visit the elderly in the nursing home, chat with the elderly; organize students to clean up, pick up garbage and so on. Student party members take the lead in doing good deeds, doing practical things, and solving difficult problems for those who need help.

Fourth, promote party building. In terms of organizational construction, our branch is committed to the development and improvement of branch team construction and member framework, set up a team to play a role in building a branch. Actively improve the level of knowledge on the branch of the party introducer, party activists and education work, party activists organized training courses, teachers patience explanation, so that students have a further understanding of the Communist Party of China, carry out practice so that students feel the real Chinese the great Communist Party, in order to guide the students to move closer to the the party organization actively.

\section{The way on "One point to promote the whole area" of exemplary role of student party members}

"A party member is a flag."'. Branch of student Party member is the outstanding group of the most influential school of all the students, play a positive role in their professional learning, social work, public welfare activities, teachers and students together to build a harmonious campus to establish a good guiding role model. The exemplary role of student party members of the branch play is an invisible force, penetration in every corner of the campus, the students imperceptibly influenced by this kind of influence, and adjust their own behavior, change their ideology and values. Play the vanguard and exemplary role of student party members to do the following:

First, learning is the pacesetter. Student Party branch must have professional knowledge and skills and comprehensive quality let other students admire in learning, should take the lead to study hard, master professional knowledge, excellent culture, improve the ability to grasp the advanced culture, with the comprehensive ability of socialist construction, a model and a model for learning.

Second, life is a model. Daily life can reflect a person's quality, branch of student party members should be strict with oneself, advocating civilized, healthy and progressive way of life. As Party members of college students, in the eyes of ordinary students have a strong affinity, a good 
foundation for the masses, should be an example in all aspects of life, driven by the surrounding students, together to create a harmonious campus living environment.

Third, be physically and mentally healthy. Health is the cost of work. Branch of student party members must adhere to exercise, develop physical and mental quality in the University, with health stirred Vital Voices, depicting the beautiful life with healthy blueprint, so as to improve the comprehensive quality, perfect personality, to improve the efficiency and quality of life and learning, and help students to consciously and actively exercise, seeking truth, $\mathrm{O}$ goodness.

Fourth, an example at work. This is an important link for college student party members to play an exemplary role. Because the vast majority of students party members of college students cadres, the work should be conscientious, hard work, solid work, establish a good sense of service, their requirements with more stringent standards, and strive to create first-class achievements, cultivate the spirit of service for the people in practice.

Fifth, manage class. Student party members should take the initiative to request as class cadres or as a junior assistant teacher in charge and contact work, the class is responsible for work, one can carry out the fine style of study class to create work, also can understand all aspects related to students' learning, life and psychological problems, and actively reflect to the school the relevant functional departments, to be solved and implemented.

College student party members play an important role in the construction of academic atmosphere and the Party Construction in Colleges and universities. Giving full play to the vanguard exemplary role of college student party members is conducive to improving the quality of personnel training in Colleges and universities, and promoting the smooth development of Party building work in Colleges and universities. At present, part of the student party members' awareness of service is weak, and the exemplary role of the vanguard is not in place. The reasons are not only for the students, but also for the university. As the education management workers in Colleges and universities, we must strengthen the ideological education of students, student members of the party strictly; perfecting the system of Party building, strengthen the management of the party after the Party member of students; broaden the student party members play a role in the practice of channels, provide a broad platform for the students to play an exemplary role of Party members. Using these measures to promote the exemplary role of student party members to play well.

\section{Acknowledgements}

The paper is the central task of the Communist Youth League: the research results of the evaluation of College Students' entrepreneurial ability from the perspective of the Communist Youth league.(NO:2017LX043).

\section{References}

[1] Zhang Zhengwu. Some thoughts on giving full play to the exemplary role of college student party members [J]. learning monthly.2010 (06)

[2] Cai Kanin, Luo Ruoxi, Chen Liang, Wu Huifei. Ruby, play their vanguard role in practice and experience -- Taking Zhaoqing University student party members with a class system as an example [J]. Heihe journal, 2011, (04): 54-56.

[3] Jin Ling, Yin Chunhua. Mechanism innovation of college student party members' vanguard exemplary role in the perspective of Party members [J]. Journal of Jilin Institute of Education (first part), 2015,31 (05): 61-62.

[4] Zhang Xuan. Research on re education of college student party members [D]. Jiangxi University of Science and Technology, 2015.

[5] Li Lin. Give full play to the exemplary role of college student party members, [J]. statistics and management, 2014, (05): 151-152. 
[6] Mao Ben, Wang Chao. How to give full play to the exemplary role of Party members of college students [J]. Education Forum, 2017, (05): 40-41. 